
\title{
25 Research Soure \\ Calcium Peroxide Promoted Anaerobic Co-digestion of Plant Waste and Excess Sludge to Produce Methane
}

\section{Yongliang Wang ( $\sim$ wangyongliang017@sina.com )}

Jiangsu Urban and Rural Construction College

Xiaohui Zhou

Hebei Agricultural University

Bin Dai

Suzhou Yuanke Ecological Construction Group

Xiaoqiang Zhu

Jiangsu Vocational College of Urban and Rural Construction

\section{Research Article}

Keywords: Strong oxidant, Optimal mixing ratio, C/N, Anaerobic fermentation, Release of organic matter, Key enzymes

Posted Date: March 23rd, 2021

DOl: https://doi.org/10.21203/rs.3.rs-339830/v1

License: (c) (i) This work is licensed under a Creative Commons Attribution 4.0 International License. Read Full License

Version of Record: A version of this preprint was published at Environmental Science and Pollution Research on April 24th, 2021. See the published version at https://doi.org/10.1007/s11356-021-14055-6. 


\section{Abstract}

Plant waste (PW) and excess sludge (ES) are two main organic matters of municipal solid waste. However, there are few reports on their anaerobic co-digestion. In this work, the mixed proportion of PW and ES anaerobic co digestion was first optimized at mesophilic temperature, and then the anaerobic co-digestion of PW and ES was enhanced with strong oxidant calcium peroxide (CP). The results showed that the optimal mixing ratio of PW and ES was 1/1 (in terms of volatile solids), and the $\mathrm{C} / \mathrm{N}$ of mixed digestion substrate was 23.5/1, the maximum methane production was $172.6 \mathrm{~mL} / \mathrm{g}$ (in terms of volatile solids). CP could enhance methane production from anaerobic co-digestion of PW and ES. When the content of $\mathrm{CP}$ was $0.2 \mathrm{~g} / \mathrm{g}$ (in terms of total suspended solids), the maximum methane production was $234.8 \mathrm{~mL} / \mathrm{g}$, about 1.4 times of the blank. The mechanism investigation showed that CP promoted the release of organic matter during the co-digestion, and the higher the content of $\mathrm{CP}$, the greater the release of soluble chemical oxygen demand. The presence of appropriate amount of CP promoted the activities of key enzymes in anaerobic fermentation process, and then increased the efficiency of methane production. The results of this work provide an alternative strategy for the resource utilization of PW and ES.

\section{Introduction}

With the rapid development of urban greening, the treatment of growing plants wastes (PW), such as litter, lawn trimmings and residual flowers, has caused great pressure on the urban ecological environment (Abreu et al. 2016; Perin et al. 2020). PW contains a large number of carbon sources, which is a valuable renewable resource. Generally, the main ways for PW reuse include fertilizer utilization, biochar preparation and composting (Ermolaev et al. 2019). However, the quality of compost products is difficult to control, and it will produce odor to pollute the environment (Vaverková et al. 2020). Therefore, an efficient PW processing strategy is urgently needed.

Anaerobic digestion uses the synergistic effect between microorganisms to convert organic matter into energy materials (Li et al. 2019a; Rodríguez-Valderrama et al.2020; González-Arias et al.2020). Anaerobic digestion not only reduces the volume of fermentation substrate, kills pathogens, but also obtains energy materials (Wei et al. 2018; Wang et al. 2019; Zhao et al. 2020a). Therefore, anaerobic digestion is considered to be a promising technology for $\mathrm{PW}$ treatment. Carbon/nitrogen $(\mathrm{C} / \mathrm{N})$ is a key parameter affecting anaerobic digestion, which has a significant impact on microbial activity, organic matter conversion efficiency and expression of key enzyme activities (Zahan et al. 2018). It is generally considered that the ideal $\mathrm{C} / \mathrm{N}$ ratio of anaerobic digestion is $20-30 / 1$ (Chiu et al. 1997). PW contains a lot of $\mathrm{C}$, but $\mathrm{N}$ is relatively deficient. Therefore, anaerobic digestion of $\mathrm{PW}$ alone is prone to low efficiency and poor stability. Excess sludge (ES) is the main by-product of wastewater treatment (Yang et al. 2010). ES also contains a lot of organic matter, and the inherent $\mathrm{C} / \mathrm{N}$ of ES is relatively low $(\sim 7 / 1)$ (Feng et al. 2009). Co-digestion of PW and ES has many advantages, such as toxicity dilution, and $\mathrm{C} / \mathrm{N}$ ratio balance (Du et al. 2021). The mixing ratio of PW and ES is an important index affecting co digestion. However, there are few reports on the co-digestion ratio of PW and ES. 
Calcium peroxide (CP) is a widely used and safe inorganic compound peroxide, which is considered as solid hydrogen peroxide (Qian et al. 2013). When CP is dissolved in water, hydrogen peroxide and calcium hydroxide will be released slowly, which makes the water have the characteristics of alkalinity and oxidation (Wang and Li 2016). In addition to the degradation of pollutants in water or soil, CP has also been used in the resource utilization of organic wastes in recent years. Zhang et al (2015) explored the degradation of phenolic endocrine disruptors by $\mathrm{CP}$, and analyzed the effect of $\mathrm{CP}$ on sludge dissolution and anaerobic digestion. The results showed that when the content of $\mathrm{CP}$ was $0.34 \mathrm{~g} / \mathrm{g}$ (calculated by TSS content), the reduction of VSS was as high as $27 \%$ (Zhang et al. 2015). At medium temperature, CP can promote the anaerobic fermentation of sludge to produce volatile fatty acids (VFA), and when the content of CP was $0.05-0.3 \mathrm{~g} / \mathrm{g}$, the hydrolysis and acidification performance of ES were significantly improved (Li et al 2015). In addition, CP combined with other pretreatment technologies such as microwave, ultrasound and free ammonia has also been proved to improve the ES anaerobic digestion performance (Wang et al. 2018; Li et al. 2019b). The alkaline environment caused by CP can destroy the structure of cellulose in PW and extracellular polymer in sludge, which is beneficial to be consumed by anaerobic microorganisms and biotransformation (Sträuber et al.2015). PW contains a large amount of lignocellulose, and Wang et al (2019) confirmed that CP promoted the degradation of lignocellulose and humus in ES, which provided guidance for $\mathrm{CP}$ to enhance the anaerobic co digestion of PW and ES in this work. However, up to now, there are few reports on the effect of CP on PW and ES anaerobic co-digestion, and the mechanism of CP enhancing PW and ES co-digestion is not clear.

Therefore, the feasibility of co-digestion of PW and ES was firstly evaluated in this work, and the mixing ratio of PW and ES was optimized. Secondly, the effect of CP content on anaerobic co-digestion of PW and ES was investigated, and the optimal dosage of CP was obtained. Finally, the mechanism of CP enhanced PW and ES anaerobic co-digestion was analyzed by measuring the metabolic transformation of organic matter, the activity of key enzymes in the co-digestion system. The results of this study provide an available technology for PW resource utilization, and expand the application field of CP.

\section{Materials And Methods}

\subsection{Source of the experimental materials}

PW was taken from the waste of a flower market in Changzhou, China. After the PW was retrieved, large particles of impurities, such as plastic bags and glass, are removed manually. The PW was then mechanically crushed to a particle size of less than $2.0 \mathrm{~mm}$. Then, a certain amount of tap water (the mass ratio of PW to tap water was 1/2) was added to PW to improve the water content of PW. The main characteristics of PW after treatment are as follows: $\mathrm{pH} 7.6 \pm 0.1$, total solids (TS) $84 \pm 3.2 \%$, volatile solids (VS) $75 \pm 2 \%$, protein $0.16 \pm 0.02 \mathrm{~g} / \mathrm{g}$, carbohydrate $0.44 \pm 0.05 \mathrm{~g} / \mathrm{g}$, soluble chemical oxygen demand (SCOD) $251 \pm 4 \mathrm{mg} / \mathrm{L}$.

The ES used in this study was taken from the secondary sedimentation tank of a sewage treatment plant in Changzhou, which mainly deals with urban domestic sewage. The recovered ES was filtered by a 2.0 
$\mathrm{mm}$ sieve, and then left for $24 \mathrm{~h}$. After that, the supernatant was removed manually, and the remaining ES was used for the experiment. The main features of ES were as follows: pH $7.1 \pm 0.2$, TS $12300 \pm 220$ $\mathrm{mg} / \mathrm{L}, \mathrm{VS} 7900 \pm 150 \mathrm{mg} / \mathrm{L}, \mathrm{SCOD} 52 \pm 5 \mathrm{mg} / \mathrm{L}$.

$\mathrm{CP}$ was purchased from a Biochemical Co., Ltd. in Shanghai, and the purchased CP was stored in a moisture-proof glass bottle. The main features of $\mathrm{CP}$ are as follows: white crystalline powder, odorless, the relative density 2.29 , and the melting point $275^{\circ} \mathrm{C}$.

The inoculum was taken from the sludge anaerobic reactor in our laboratory, and the main characteristics of inoculum are as follows: pH $7.1 \pm 0.2$, TSS $9800 \pm 50 \mathrm{mg} / \mathrm{L}$, VSS $6800 \pm 40 \mathrm{mg} / \mathrm{L}$, VFA $56 \pm 5 \mathrm{mg} / \mathrm{L}$, SCOD $68.5 \pm 5 \mathrm{mg} / \mathrm{L}$.

\subsection{Optimization of co-digestion ratio of PW and ES}

In this test, five groups (named R1-R5) of sequencing batch reactors (SBR) were established, and each group consisted of three identical reactors (working volume $1000 \mathrm{~mL}$ ). The reactor was equipped with mechanical agitator, and the speed of the reactor was controlled at $100 \mathrm{rpm}$. An air collecting bag was arranged above the reactor to collect the biogas produced by the anaerobic co-digestion of PW and ES. The side part of the reactor was provided with a feed inlet and a discharge port. First of all, the mixture of PW and ES was added to each reactor in different proportions, and their initial ratios were controlled to be about $1 / 0,2 / 1,1 / 1,1 / 2$, and $0 / 1$ (PW/ES, calculated by the content of VS). The initial organic matter content was controlled to be approximately equal. $\mathrm{pH}$ is the key parameter affecting the anaerobic digestion of organic matter. It is generally considered that the optimal $\mathrm{pH}$ for methanogenic archaea metabolism was in the range of 6.5-7.5. Therefore, the initial pH of PW and ES anaerobic co digestion was controlled at $7.0 \pm 0.1$ by manual addition of $4.0 \mathrm{M}$ sodium hydroxide or hydrochloric acid, but not controlled in the co-digestion process. Finally, all the reactors were placed in an air-conditioned room with a constant temperature of $25 \pm 2.0^{\circ} \mathrm{C}$ for 30 days. The optimal proportion of PW and ES was determined by measuring the co-digestion gas production of PW and ES.

\subsection{Effect of CP on the co-digestion performance of PW and ES}

According to the results in Sect. 2.2, the optimal ratio of PW and ES for anaerobic co-digestion was set at 1/1. Therefore, the initial mixing ratio of PW and ES was controlled at $1 / 1$ in this test, and the volume of mixture was $600 \mathrm{~mL}$. Then, different doses of $\mathrm{CP}$ were added to each reactor, and the contents of $\mathrm{CP}$ were $0,0.05,0.1,02$ and $0.3 \mathrm{~g} / \mathrm{g}$ (in terms of TS), respectively. The other operating conditions were consistent as those described in the Sect. 2.2. The optimal dose of CP was determined by measuring the methane production in each group.

\subsection{Analysis method}


The determination procedures of COD, SCOD, TSS and VSS are in accordance with the standard methods (APHA 1998). Protein was determined by Folin phenol method, bovine serum protein was used as standard substance, anthrone colorimetric method was used to determine polysaccharide, and glucose was used as standard substance (Lowry et al. 1951; Dubois et al. 1951). Methane was determined by gas chromatography, the model of gas chromatography instrument was GC-2010 (Shimadzu, Japan). VFA was determined by HPLC. The model of liquid chromatography was DIONEX U-3000, the column was ZORBAX SB-Aq (column length was $150 \times 4.6 \mathrm{~mm}$, diameter was 2.3), the injection volume was $10 \mu \mathrm{L}$, the column temperature was $30{ }^{\circ} \mathrm{C}$, and the UV detection wavelength was $210 \mathrm{~nm}$. C/N is the ratio of total carbon to total nitrogen, and total nitrogen is determined by Kjeldahl method after boiling. The functional enzymes in anaerobic digestion process include protease, amylase, filter paper enzyme, CMC enzyme and F420 coenzyme, and their determination procedure are shown in Ref. (Chabrière et al. 1999; Zhu et al.2020a; Gupta et al. 2012),

\subsection{Statistical analysis.}

All the experiments were performed in triplicate. The results were statistically significant when the probability was less than $0.05(p<0.05)$.

\section{Results And Discussion}

\subsection{Optimization of anaerobic co digestion of PW and ES}

Mixing ratio is the key parameter of anaerobic co-digestion, which affects the performance of codigestion (Haider et al. 2015). The effect of co-digestion ratio of PW and ES on the methane yield was presented in in Fig. 1. It can be clearly found that the methane production in each reactor showed a sharp rise first, then a steady increase, and finally a basically stable trend. However, different proportions of PW and ES have a great impact on the cumulative methane production. In R1 or R5, PW or ES were digested alone, and the maximum cumulative methane production was $103.2 \mathrm{~mL} / \mathrm{g}$ and $128.6 \mathrm{~mL} / \mathrm{g}$, respectively, which was similar to the previous reports (Wang et al. 2019). When PW and ES were co-digested, the cumulative methane production was significantly increased (Table S1), and when the ratio of PW to ES reduced from $2 / 1$ to $1 / 1$, the maximum cumulative methane production increased from $146.5 \mathrm{~mL} / \mathrm{g}$ to $172.6 \mathrm{~mL} / \mathrm{g}$. However, when the ratio of PW to ES further reduced to $1 / 2$, the cumulative maximum methane production decreased to $136.4 \mathrm{~mL} / \mathrm{g}$, but still higher than that of PW or ES digestion alone. The above experimental results clearly show that co-digestion of PW and ES improved methane production.

Figure 2 further showed the daily methane production during the co-digestion of PW and ES. As shown in Fig. 2, the daily methane production rate in each group showed two peaks, about on $2 \mathrm{~d}$ and $20 \mathrm{~d}$, respectively. The first peak was due to the high content of digestive substrate and the low concentration of ammonia nitrogen, which led to the high activity of methanogens. The second peak appeared mainly because methanogenic microorganisms adapted to the digestion and operation conditions. The mixing ratio of PW and ES also had a great impact on the daily methane production. In R1, the daily methane production rate was low during the first $15 \mathrm{~d}$, which was mainly due to the high content of refractory 
organic matter (lignin, cellulose, etc.) in PW (Croce et al. 2016). When the ratio of PW to ES reduced to $1 / 1$, the daily methane production rate reached the maximum value of the experimental group, indicating that the daily methane production in R3 was the best. However, when the ratio of PW to ES further reduced, the daily methane production decreased slightly.

The mixing of PW and ES mainly affected the $\mathrm{C} / \mathrm{N}$ ratio in the fermentation substrate, because $\mathrm{PW}$ was a kind of organic matter with high carbon content, while ES was a kind of organic waste with high proportion of nitrogen. Table 1 showed the variation of $\mathrm{C} / \mathrm{N}$ ratio of each reactor. It can be seen from Table 1 that the mixed ratio of PW and ES reduced from $1 / 0$ to $1 / 1$, the $\mathrm{C} / \mathrm{N}$ in the fermentation substrate reduced from $34.1 / 1$ to $23.5 / 1$, and the ratio of $\mathrm{PW}$ and $\mathrm{ES}$ further reduced to $0 / 1$, and the $\mathrm{C} / \mathrm{N}$ in the fermentation substrate also reduced to $7.2 / 1$. $\mathrm{C} / \mathrm{N}$ is one of the key factors affecting the activity of anaerobic digestion microorganisms, which has an important impact on the transformation of organic matter and the expression of key enzyme activities (Dai et al. 2016; Paul and Dutta 2018). Previous studies have shown that the optimal $\mathrm{C} / \mathrm{N}$ for anaerobic digestion was in the range of 20-30/1 (Zahan et al. 2018; Parkin and Owen 1986). When the ratio of PW and ES was $1 / 1$, the $\mathrm{C} / \mathrm{N}$ ratio of fermentation substrate was 23.5/1, which was in the range of optimal digestion ratio. Although the $\mathrm{C} / \mathrm{N}$ ratio in $\mathrm{R} 2$ was also in the optimal range, the PW content in R2 was higher and the refractory components (lignin, hemicellulose, etc.) were more, which were difficult to be hydrolyzed. Therefore, the optimal mixture ratio of PW and ES to produce methane was 1/1.

Table 1

Changes of $\mathrm{C} / \mathrm{N}$ ratio of digestive matrix with $\mathrm{PW}$ and $\mathrm{ES}$ mixture ratio

\begin{tabular}{|llllll|}
\hline Reactor & R1 & R2 & R3 & R4 & R5 \\
\hline C/N & $34.1 \pm 2.3 / 1$ & $28.6 \pm 1.3 / 1$ & $23.5 \pm 1.6 / 1$ & $16.5 \pm 1.1 / 1$ & $7.2 \pm 0.8 / 1$ \\
\hline
\end{tabular}

\subsection{CP enhanced the co-digestion of PW and ES}

Figure 3 presented the effect of CP content on the co- digestion of PW and ES to produce methane. It can be clearly seen that the change trend of methane in each reactor showed a sharp increase at first and then a slow change trend. However, when $\mathrm{CP}$ was present in the co-digestion system, the methane production potential of the mixed matrix changed greatly. When the content of CP increased from 0 to 0.2 $\mathrm{g} / \mathrm{g}$, the maximum cumulative methane production increased from $172.6 \mathrm{~mL} / \mathrm{g}$ to $234.8 \mathrm{~mL} / \mathrm{g}$. However, further increasing the content of $\mathrm{CP}$ to $0.3 \mathrm{~g} / \mathrm{g}$, the maximum cumulative methane production decreased slightly and decreased to $209.7 \mathrm{~mL} / \mathrm{g}$, but it was still about 1.2 times of the blank. CP has the characteristics of strong oxidation, and the presence of excess CP can inhibit the activity of methanogenic archaea, thereby reducing methane production. It can be clearly found that $\mathrm{CP}$ promoted the co-digestion of PW and ES to produce methane. 
Methane is the end product of anaerobic digestion of organic matter. In the blank, the maximum cumulative methane production time could be considered as $21 \mathrm{~d}$ (Fig. 2). The maximum cumulative methane production time was slightly delayed with the ES digestion time alone, which may be related to the presence of refractory hemicellulose and ligneous acid in the digestion matrix in this work (Mustafa et al. 2016; Mamimin et al. 2020). When CP was present in the digestive system, the maximum cumulative methane production time was shortened to $19 \mathrm{~d}, 2$ days earlier than the blank. The reduction of the optimal digestion time is of great significance in practical engineering, which can improve the treatment efficiency of organic matter (Qu et al. 2020). Therefore, the results obtained in this work clearly showed $\mathrm{CP}$ improved the co digestion efficiency of PW and ES, and shortened the optimal digestion time. The mechanism of CP enhancing co digestion of PW and ES would be described in detail in the following chapters.

It is considered that anaerobic digestion of organic matter must go through disintegration stage, and the change of SCOD in fermentation system can reflect the degree of disintegration (Liu et al. 2019; Kuang et al.2020a; Dong et al. 2020). As shown in Fig. 4, the concentration of SCOD in each group increased first and then decreased slowly. However, the content of CP greatly changed the concentration of SCOD in the fermentation broth. It can be clearly seen that the higher the content of $C P$, the concentration of SCOD in fermentation broth. For example, in the blank, the maximum content of SCOD was $1584 \mathrm{mg} / \mathrm{L}$, and when the content of CP was $0.05 \mathrm{~g} / \mathrm{g}$, the maximum concentration of SCOD increased to $1826 \mathrm{mg} / \mathrm{L}$. The concentration of CP further increased to $0.3 \mathrm{~g} / \mathrm{g}$, the maximum concentration of SCOD also increased to $2793 \mathrm{mg} / \mathrm{L}$, which was about 1.7 times of the blank. When CP was dissolved in the fermentation system, calcium hydroxide and hydrogen peroxide were released slowly, which increased the $\mathrm{pH}$ value of fermentation (Wang et al. 2018). Previous studies have shown that alkaline pH was conducive to the dissolution of cellulose and hemifiber in the straw, which leaded to the increase of degradable organic matter content (Mancini et al. 2018; Bolado-Rodríguez et al. 2016). PW is rich in carbon sources, most of which are cellulose, lignocellulose and so on. The degradation of lignocellulose can be enhanced by CP (Wang et al. 2019), which improved the anaerobic digestion performance of PW. In addition, alkaline environment was conducive to the decomposition of extracellular polymer in ES, releasing extracellular organic matter and increasing the content of dissolved organic matter in fermentation broth (Chi et al. 2011; Kim et al. 2013; Kuang et al.2020b). The hydrogen peroxide released by CP can also promote the transformation of refractory organic matter from PW or ES, thus increasing the concentration of SCOD (Ping et al. 2018).

Protein and polysaccharide are the main organic compounds in ES. This work also explored the effect of $\mathrm{CP}$ on the dissolution of the two organic compounds. As shown in Fig. 5, the change trend of soluble protein and soluble polysaccharide was similar to that of SCOD. The higher the content of CP, the greater the release of soluble protein and polysaccharide. For example, when the content of CP was $0.3 \mathrm{~g} / \mathrm{g}$, the contents of soluble protein and polysaccharide on $8 \mathrm{~d}$ were $535 \mathrm{mg} / \mathrm{L}$ and $442 \mathrm{mg} / \mathrm{L}$ (calculated by COD concentration), respectively, which were 1.9 and 2.2 times of those in the blank. In this study, the concentration of polysaccharides was high, accounting for about $36 \%$ of the total SCOD, which was significantly higher than the results of ES anaerobic digestion alone reported before (Wang et al. 2019). 
The reason for this phenomenon may be due to the large amount of PW in the digestive matrix, and there was a certain amount of polysaccharide in the PW. The strong oxidation of $\mathrm{CP}$ increased the release of organic matter from fermentation substrate, which provided sufficient materials for subsequent acidification and methanation (Liu et al. 2019).

\subsection{Effect of CP on yield of VFA during the co-digestion of PW and ES}

VFA is a key intermediate in organic anaerobic fermentation process, which has an important impact on the utilization and activity of methanogens. As shown in Fig. 6, CP can affect VFA accumulation during the co- digestion of PW and ES, and the maximum accumulation of VFA was closely related to the CP content. When the content of $\mathrm{CP}$ increased from 0 to $0.2 \mathrm{~g} / \mathrm{g}$, the maximum accumulation of VFA increased from $361 \mathrm{mg} / \mathrm{L}$ to $751 \mathrm{mg} / \mathrm{L}$ (calculated by COD concentration), which indicated that increasing CP content promoted VFA accumulation. It should be noted that when the content of CP increased to $0.3 \mathrm{~g} / \mathrm{g}$, the accumulation of VFA was inhibited to a certain extent, and the maximum accumulation of VFA was $503 \mathrm{mg} / \mathrm{L}$, lower than that of $0.2 \mathrm{~g} / \mathrm{g}$ CP group, but still higher than that of blank. The conversion of dissolved organic matter to VFA requires the metabolism of microorganisms, which is a biochemical reaction. The change of $\mathrm{pH}$ in this study is shown in Fig.S1. The results showed that the higher the CP content, the greater the increase of $\mathrm{pH} .0 .3 \mathrm{~g} / \mathrm{g}$ CP reduced the content of VFA, which may be due to the fact that the maximum $\mathrm{pH}$ was beyond the tolerance of acidifying microorganisms (Zhao et al. 2010; Lin et al. 2013). The high pH produced by high dose of CP had a negative effect on microorganisms, and the VFA content was not the highest in the presence of $0.3 \mathrm{~g} / \mathrm{g}$ CP.

VFA is the main substrate in the process of methane production, and the components of VFA can also affect the accumulation of methane. As shown in the appendix, CP could affect the proportion of VFA components and promote the relative percentage of acetate. When the content of $\mathrm{CP}$ increased from 0 to $0.1 \mathrm{~g} / \mathrm{g}$, the proportion of acetate increased from $42.3-49.5 \%$, indicating that proper increase of CP content was beneficial to the biogenesis of acetate. Further increasing the content of CP had little effect on the increase of acetate percentage. In the blank, propionate was also a major VFA component, accounting for about $26.5 \%$, while the increase of CP content reduced the proportion of propionate, especially when the content of CP was $0.2 \mathrm{~g} / \mathrm{g}$, the proportion of propionate decreased to $24.3 \%$. Previous studies have shown that methanogens were more likely to consume acetate and convert to methane, while more difficult to consume propionate (Zhao et al. 2019; Zhang et al. 2021). In this work, the increase of CP content increased the proportion of acetic acid and decreased the proportion of propionic acid, which also provided the basis for improving the activity of methanogens.

\subsection{Effect of CP on VSS reduction during co-digestion of PW and ES}


One of the main functions of anaerobic digestion is to reduce organic matter (Li et al. 2011; Zhao et al.2020b; Zhu et al.2020b). The effect of CP dosage on VSS reduction was also evaluated. As shown in Fig. 7, the presence of CP improved the reduction rate of VSS, and the higher the content of CP, the greater the reduction rate of VSS. In the blank, the reduction rate of VSS was about $26.5 \%$, while when the content of CP was $0.05 \mathrm{~g} / \mathrm{g}$, the reduction rate of VSS was slightly increased to $26.9 \%$, indicating that the reduction rate of low content $\mathrm{CP}$ was not obvious $(p>0.05)$. When the content of $\mathrm{CP}$ was further increased to $0.2 \mathrm{~g} / \mathrm{g}$ and $0.3 \mathrm{~g} / \mathrm{g}$, the reduction rate of VSS increased to $32.6 \%$ and $33.9 \%$, which were 1.23 and 1.27 times of the blank, respectively, indicating that high concentration of CP significantly increased the content of organic matter in the PW and ES co-digestion system. Previous studies have shown that the removal rate of VSS was consistent with the gas production rate, that was, the higher the removal efficiency of VSS, the higher the gas production (Rafique et al. 2010; Li et al. 2019b). However, in this work, $0.3 \mathrm{~g} / \mathrm{g}$ CP led to the highest removal rate of VSS, but the content of CP in the group with the highest gas production rate was $0.2 \mathrm{~g} / \mathrm{g}$. This inconsistency may be due to the strong oxidation effect of $0.3 \mathrm{~g} / \mathrm{g}$ CP on anaerobes, thus inhibiting the activity of methanogens.

\subsection{Effect of CP on the activities of key enzymes in the co- digestion of PW and ES}

Anaerobic digestion is mainly carried out under the control of anaerobic microorganisms and key enzymes. The activities of key enzymes can reflect the activities of microorganisms (Zhao et al.2020c; Zheng et al.2021a; Zhu et al.2020c). Protease and amylase are the key enzymes to decompose protein and polysaccharide in ES, while filter paper enzyme and CMC enzyme are responsible for the degradation of total lignocellulose and cellulose in PW (Romero-Güiza et al. 2016; Gu et al. 2014). As shown in Fig. 8, the presence of $\mathrm{CP}$ has a great impact on the activity of hydrolysis and acidification enzymes in anaerobic digestion process. For example, when the content of $\mathrm{CP}$ was $0.2 \mathrm{~g} / \mathrm{g}$, the relative activities of protease and amylase were $115 \%$ and $109 \%$, respectively, which were significantly higher than those of blank group. Similar experimental results were also found in filter paper enzyme and CMC enzyme. The presence of $\mathrm{CP}$ promoted the dissolution and release of refractory organic compounds in PW and ES, thus providing the favorable conditions for the hydrolysis of key enzymes. In addition, high dose of CP inhibited the above key enzymes, especially filter paper enzyme and CMC enzyme, which may be related to the strong oxidation of CP. Coenzyme F420 is unique to methanogens and is sensitive to the external environment (Zheng et al. 2020b). The presence of CP decreased the activity of F420, and the higher the content of $\mathrm{CP}$, the greater the inhibition of $\mathrm{F} 420$. This phenomenon may be due to the increase of oxidative stress by $\mathrm{CP}$, and the optimum pH range of methanogens was 7.0-8.0 (Lay et al. 1997). CP can strengthen PW and ES anaerobic digestion to produce methane mainly because CP promoted the release of organic matter and provides sufficient material guarantee for the digestion process. Although it has a little inhibition on F420 enzyme activity, it promotes methane production as a whole.

\section{Conclusion}


PW and ES anaerobic co-digestion was implemented in this work. The results showed that the optimal mixing ratio of $\mathrm{PW}$ and ES co-digestion was 1/1, and the maximum methane production is $172.6 \mathrm{~mL} / \mathrm{g}$, which was significantly higher than that of other groups. The strong oxidant CP was used to strengthen the anaerobic co-digestion of PW and ES. The presence of CP promoted the release of organic matter in the process of anaerobic co-digestion of $\mathrm{PW}$ and $\mathrm{ES}$, and the content of $\mathrm{CP}$ was positively correlated with the amount of organic matter released. The optimal dose of CP was $0.2 \mathrm{~g} / \mathrm{g}$, and at this time, the maximum accumulation of methane was $234.8 \mathrm{~mL} / \mathrm{g}$, about 1.4 times of the blank. Enzyme activity analysis showed appropriate amount of CP promoted the activity of hydrolase, but decreased the activity of coenzyme F420.

\section{Declarations}

\section{* Ethics approval and consent to participate}

Not applicable

\section{* Consent for publication}

Not applicable

\section{* Availability of data and materials}

Not applicable

\section{* Competing interests}

The authors declare that they have no competing interests.

\section{* Funding}

This work was financially supported by the special project of talent introduction of Hebei Agricultural University (YJ2020043)

\section{* Authors' contributions}

YW: Conceptualization, Writing- original draft, Writing - review \& editing. X ZH: Investigation, Validation, Writing - review \& editing. B D $\otimes$ Writing - review \& editing. X ZH: Investigation, Validation. All authors read and approved the final manuscript.

\section{* Acknowledgements}

Not applicable

\section{References}


1. Abreu A A, Tavares F, Alves M M, Pereira M A (2016) Boosting dark fermentation with co-cultures of extreme thermophiles for biohythane production from garden waste. Bioresour Technol 219: 132138. https://doi.org/10.1016/j.biortech.2016.07.096

2. APHA (1998) Standard Methods for the Examination of Water and Wastewater, 20th ed. American Public Health Association, Washington, DC.

3. Bolado-Rodríguez S, Toquero C, Martín-Juárez J, Travaini R, García-Encina P A (2016) Effect of thermal, acid, alkaline and alkaline-peroxide pretreatments on the biochemical methane potential and kinetics of the anaerobic digestion of wheat straw and sugarcane bagasse. Bioresour Technol 201: 182-190. https://doi.org/10.1016/j.biortech.2015.11.047

4. Chabrière E, Charon M H, Volbeda A, Pieulle L, Hatchikian E C, Fontecilla-Camps J C (1999) Crystal structures of the key anaerobic enzyme pyruvate: ferredoxin oxidoreductase, free and in complex with pyruvate. Nat Struct Biol 6(2): 182-190. https://doi.org/10.1038/5870

5. Chi Y, Li Y, Fei X, Wang S, Yuan H (2011) Enhancement of thermophilic anaerobic digestion of thickened waste activated sludge by combined microwave and alkaline pretreatment. J Environ Sci 23(8): 1257-1265. https://doi.org/10.1016/S1001-0742(10)60561-X

6. Chiu Y C, Chang C N, Lin J G, Huang S J (1997) Alkaline and ultrasonic pretreatment of sludge before anaerobic digestion. Water Sci Technol 36(11): 155-162. https://doi.org/10.1016/S02731223(97)00681-1

7. Croce S, Wei Q, D'Imporzano G, Dong R, Adani F (2016) Anaerobic digestion of straw and corn stover: The effect of biological process optimization and pre-treatment on total bio-methane yield and energy performance. Biotechnol Adv 34(8): 1289-1304. https://doi.org/10.1016/j.biotechadv.2016.09.004

8. Dai X, Li X, Zhang D, Chen Y, Dai L (2016) Simultaneous enhancement of methane production and methane content in biogas from waste activated sludge and perennial ryegrass anaerobic codigestion: The effects of $\mathrm{pH}$ and $\mathrm{C} / \mathrm{N}$ ratio. Bioresour Technol 216: 323-330. https://doi.org/10.1016/j.biortech.2016.05.100

9. Dong, H., Li, M., Jin, Y., Wu, Y., Huang, C., Yang, J., 2020. Preparation of graphene-like porous carbons with enhanced thermal conductivities from lignin nano-particles by combining hydrothermal carbonization and pyrolysis. Front. Energy Res. 8:148. https://doi:10.3389/fenrg.2020.00148

10. Du M, Liu X, Wang D, Yang Q, Duan A, Chen H, Liu Y, Wang Q, Ni B J (2021). Understanding the fate and impact of capsaicin in anaerobic co-digestion of food waste and waste activated sludge. Water Res 188: 116539. https://doi.org/10.1016/j.watres.2020.116539

11. Dubois M, Gilles K A, Hamilton J K, Rebers P A, Smith F (1951) A colorimetric method for the determination of sugars. Nature 168(4265): 167-167. https://doi.org/10.1038/168167a0

12. Ermolaev E, Sundberg C, Pell M, Smårs S, Jönsson H (2019) Effects of moisture on emissions of methane, nitrous oxide and carbon dioxide from food and garden waste composting. J Clean Prod 240: 118165. https://doi.org/10.1016/j.jclepro.2019.118165 
13. Feng L, Chen Y, Zheng X. (2009). Enhancement of waste activated sludge protein conversion and volatile fatty acids accumulation during waste activated sludge anaerobic fermentation by carbohydrate substrate addition: the effect of pH. Environ Sci Technol 43(12), 4373-4380. https://doi.org/10.1021/es8037142

14. Gu Y, Chen X, Liu Z, Zhou X, Zhang Y (2014) Effect of inoculum sources on the anaerobic digestion of rice straw. Bioresour Technol 158: 149-155. https://doi.org/10.1016/j.biortech.2014.02.011

15. González-Arias J, Gil M V, Fernández R Á, Martínez E J, Fernández C, Papaharalabos G, Gómez X (2020). Integrating anaerobic digestion and pyrolysis for treating digestates derived from sewage sludge and fat wastes. Environ Sci Pollut Res 27(26): 32603-32614. https://doi.org/10.1007/s11356020-09461-1

16. Gupta P, Samant K, Sahu A (2012) Isolation of cellulose-degrading bacteria and determination of their cellulolytic potential. Int J Microbiol 2012. https://doi.org/10.1155/2012/578925

17. Haider M R, Yousaf S, Malik R N, Visvanathan C (2015) Effect of mixing ratio of food waste and rice husk co-digestion and substrate to inoculum ratio on biogas production. Bioresour Technol 190: 451457. https://doi.org/10.1016/j.biortech.2015.02.105

18. Kim J, Yu Y, Lee C (2013) Thermo-alkaline pretreatment of waste activated sludge at lowtemperatures: effects on sludge disintegration, methane production, and methanogen community structure. Bioresour Technol 144: 194-201. https://doi.org/10.1016/j.biortech.2013.06.115

19. Kuang Y, Gao Y, Zhang J, Zhao J, Luo S, Zhang D, Lu C, Sun Y (2020a) Effect of initial pH on the sludge fermentation performance enhanced by aged refuse at low temperature of $10^{\circ} \mathrm{C}$. Environ Sci Pollut Res 27: 31468-31476 https://doi.org/10.1007/s11356-020-09306-x

20. Kuang Y, Zhao J, Gao Y, Lu C, Luo S, Sun Y, Zhang D (2020b) Enhanced hydrogen production from food waste dark fermentation by potassium ferrate pretreatment. Environ Sci Pollut Res 27:1814518156. https://doi.org/10.1007/s11356-020-08207-3

21. Lay J J, Li Y Y, Noike T, Endo J, Ishimoto S (1997) Analysis of environmental factors affecting methane production from high-solids organic waste. Water Sci Technol 36(6-7): 493-500. https://doi.org/10.1016/S0273-1223(97)00560-X

22. Li Y, Park S Y, Zhu J (2011) Solid-state anaerobic digestion for methane production from organic waste. Renew Sustain Energ Rev 15(1), 821-826. https://doi.org/10.1016/j.rser.2010.07.042

23. Li Y, Chen Y, Wu J (2019a) Enhancement of methane production in anaerobic digestion process: $A$ review. Appl Energy 240: 120-137. https://doi.org/10.1016/j.apenergy.2019.01.243

24. Li Y, Wang J, Zhang A, Wang $L$ (2015). Enhancing the quantity and quality of short-chain fatty acids production from waste activated sludge using $\mathrm{CaO}_{2}$ as an additive. Water Res 83, 84-93. https://doi.org/10.1016/j.watres.2015.06.021

25. Li X, Liu Y, Xu Q, Liu X, Huang X, Yang J, Wang D, Wang Q, Liu Y, Yang Q (2019b). Enhanced methane production from waste activated sludge by combining calcium peroxide with ultrasonic: Performance, mechanism, and implication. Bioresour Technol 279:108-116. https://doi.org/10.1016/j.biortech.2019.01.115 
26. Lin L, Wan C, Liu X, Lee D J, Lei Z, Zhang Y, Tay J H (2013) Effect of initial pH on mesophilic hydrolysis and acidification of swine manure. Bioresour Technol 136: 302-308. https://doi.org/10.1016/j.biortech.2013.02.106

27. Liu X, Xu Q, Wang D, Yang Q, Wu Y, Li Y, Fu Q, Yang F, Liu Y, Ni B, Wang Q, Li X, (2019) Thermalalkaline pretreatment of polyacrylamide flocculated waste activated sludge: process optimization and effects on anaerobic digestion and polyacrylamide degradation. Bioresour Technol 281: 158167. https://doi.org/10.1016/j.biortech.2019.02.095

28. Lowry O H, Rosebrough N J, Farr A L, Randall R J (1951) Protein measurement with the Folin phenol reagent. J Biol Chem 193: 265-275.

29. Mancini G, Papirio S, Riccardelli G, Lens P N, Esposito G (2018) Trace elements dosing and alkaline pretreatment in the anaerobic digestion of rice straw. Bioresour Technol 247: 897-903. https://doi.org/10.1016/j.biortech.2017.10.001

30. Mamimin C, Chanthong S, Leamdum C, Sompong O, Prasertsan P (2020). Improvement of empty palm fruit bunches biodegradability and biogas production by integrating the straw mushroom cultivation as a pretreatment in the solid-state anaerobic digestion. Bioresour Technol 319: 124227. https://doi.org/10.1016/j.biortech.2020.124227

31. Mustafa A M, Poulsen T G, Sheng K (2016) Fungal pretreatment of rice straw with Pleurotus ostreatus and Trichoderma reesei to enhance methane production under solid-state anaerobic digestion. Appl Energy 180: 661-671. https://doi.org/10.1016/j.apenergy.2016.07.135

32. Parkin G F, Owen W F (1986) Fundamentals of anaerobic digestion of wastewater sludges. J Environ Eng 112(5):867-920.

33. Paul S, Dutta A (2018) Challenges and opportunities of lignocellulosic biomass for anaerobic digestion. Resour Conserv Recycl 130:164-174. https://doi.org/10.1016/j.resconrec.2017.12.005

34. Perin J K H, Borth P L B, Torrecilhas A R, da Cunha L S, Kuroda E K, Fernandes F (2020) Optimization of methane production parameters during anaerobic co-digestion of food waste and garden waste. $J$ Clean Prod 272: 123130. https://doi.org/10.1016/j.jclepro.2020.123130

35. Ping Q, Lu X, Zheng M, Li Y (2018) Effect of CaO2 addition on anaerobic digestion of waste activated sludge at different temperatures and the promotion of valuable carbon source production under ambient condition. Bioresour Technol 265: 247-256. https://doi.org/10.1016/j.biortech.2018.06.007

36. Qian Y, Zhou X, Zhang Y, Zhang W, Chen J (2013) Performance and properties of nanoscale calcium peroxide for toluene removal. Chemosphere, 91(5): 717-723.

https://doi.org/10.1016/j.chemosphere.2013.01.049

37. Qu J, Sun Y, Awasthi M K, Liu Y, Xu X, Meng X, Zhang H (2020) Effect of different aerobic hydrolysis time on the anaerobic digestion characteristics and energy consumption analysis. Bioresour Technol 320: 124332. https://doi.org/10.1016/j.biortech.2020.124332

38. Rafique R, Poulsen T G, Nizami A S, Murphy J D, Kiely G (2010) Effect of thermal, chemical and thermo-chemical pre-treatments to enhance methane production. Energy 35(12): 4556-4561. https://doi.org/10.1016/j.energy.2010.07.011 
39. Romero-Güiza M S, Vila J, Mata-Alvarez J, Chimenos J M, Astals S (2016) The role of additives on anaerobic digestion: a review. Renew Sustain Energ Rev 58: 1486-1499. https://doi.org/10.1016/j.rser.2015.12.094

40. Rodríguez-Valderrama S, Escamilla-Alvarado C, Rivas-García P, Magnin J P, Alcalá-Rodríguez M, García-Reyes R. B (2020) Biorefinery concept comprising acid hydrolysis, dark fermentation, and anaerobic digestion for co-processing of fruit and vegetable wastes and corn stover. Environ Sci Pollut Res 27(23): 28585-28596. https://doi.org/10.1007/s11356-020-08580-z

41. Sträuber H, Bühligen F, Kleinsteuber S, Nikolausz M, Porsch K (2015) Improved anaerobic fermentation of wheat straw by alkaline pre-treatment and addition of alkali-tolerant microorganisms. Bioengineering, 2(2), 66-93. https://doi.org/10.3390/bioengineering2020066

42. Vaverková M D, Adamcová D, Winkler J, Koda E, Petrželová L, Maxianová A (2020) Alternative method of composting on a reclaimed municipal waste landfill in accordance with the circular economy: Benefits and risks. Sci Total Environ 137971. https://doi.org/10.1016/j.scitotenv.2020.137971

43. Wang D, He D, Liu X, Xu Q, Yang Q, Li X, Liu Y, Wang Q, Ni B, Li H (2019) The underlying mechanism of calcium peroxide pretreatment enhancing methane production from anaerobic digestion of waste activated sludge. Water Res 164, 114934. https://doi.org/10.1016/j.watres.2019.114934

44. Wang D, Shuai K, Xu Q, Liu X, Li Y, Liu Y, Wang Q, Li X, Zeng G, Yang Q (2018) Enhanced short-chain fatty acids production from waste activated sludge by combining calcium peroxide with free ammonia pretreatment. Bioresour Technol 262: 114-123.

https://doi.org/10.1016/j.biortech.2018.04.081

45. Wang J, Li Y (2016) Synergistic pretreatment of waste activated sludge using $\mathrm{CaO} 2$ in combination with microwave irradiation to enhance methane production during anaerobic digestion. Appl Energy 183: 1123-1132. https://doi.org/10.1016/j.apenergy.2016.09.042

46. Wei J, Hao X, van Loosdrecht M C, Li J (2018) Feasibility analysis of anaerobic digestion of excess sludge enhanced by iron: a review. Renew Sustain Energ Rev 89: 16-26.

47. Yang Q, Luo K, Li X M, Wang D B, Zheng W, Zeng G M, Liu J J (2010) Enhanced efficiency of biological excess sludge hydrolysis under anaerobic digestion by additional enzymes. Bioresour Technol 101(9): 2924-2930. https://doi.org/10.1016/j.biortech.2009.11.012

48. Zahan Z, Othman M Z, Muster T H (2018) Anaerobic digestion/co-digestion kinetic potentials of different agro-industrial wastes: A comparative batch study for $\mathrm{C} / \mathrm{N}$ optimisation. Waste Manage 71: 663-674. https://doi.org/10.1016/j.wasman.2017.08.014

49. Zhang A, Wang J, Li Y (2015). Performance of calcium peroxide for removal of endocrine-disrupting compounds in waste activated sludge and promotion of sludge solubilization. Water Res 71: 125139. https://doi.org/10.1016/j.watres.2015.01.005

50. Zhang J, Zhao J, Sun Y, Xin M, Zhang D, Bian R (2021). Mechanisms of emerging pollutant Dechlorane Plus on the production of short-chain fatty acids from sludge anaerobic fermentation. Environ Sci Pollut Res https://doi.org/10.1007/s11356-021-13101-7. 
51. Zhao J, Jing Y, Zhang J, Sun Y, Wang Y, Wang H, Bi X (2019). Aged refuse enhances anaerobic fermentation of food waste to produce short-chain fatty acids. Bioresour Technol 289: 121547. https://doi.org/10.1016/j.biortech.2019.121547

52. Zhao J, Xin M, Zhang J, Sun Y, Luo S, Wang H, Wang Y, Bi X (2020a). Diclofenac inhibited the biological phosphorus removal: performance and mechanism. Chemosphere 243: 125380. https://doi.org/10.1016/j.chemosphere.2019.125380

53. Zhao J, Zhang J, Zhang D, Hu Z, Sun Y (2020b) Effect of emerging pollutant fluoxetine on the excess sludge anaerobic digestion. Sci Total Environ 752: 141932. https://doi.org/10.1016/j.scitotenv.2020.141932

54. Zhao J, Yuan Q, Sun Y, Zhang J, Zhang D, Bian R (2020c). Effect of fluoxetine on enhanced biological phosphorus removal using a sequencing batch reactor. Bioresour Technol 320: 124396. https://doi.org/10.1016/j.biortech.2020.124396

55. Zhao Y, Chen Y, Zhang D, Zhu X (2010) Waste activated sludge fermentation for hydrogen production enhanced by anaerobic process improvement and acetobacteria inhibition: the role of fermentation pH. Environ Sci Technol 44(9), 3317-3323. https://doi.org/10.1021/es902958c

56. Zheng, Y., Yu, Y., Lin, W., Jin, Y., Yong, Q., Huang, C., 2021a. Enhancing the enzymatic digestibility of bamboo residues by biphasic phenoxyethanol-acid pretreatment. Bioresour. Technol. 124691. https://doi.org/10.1016/j.biortech.2021.124691

57. Zheng, L., Yu, P., Zhang, Y., Wang, P., Yan, W., Guo, B., Huang, C., Jiang, Q., 2021b. Evaluating the bioapplication of biomacromolecule of lignin-carbohydrate complexes (LCC) from wheat straw in bone metabolism via ROS scavenging. Int. J. Biol. Macromol. doi.org/10.1016/j.jijbiomac.2021.01.103

58. Zhu, J., Zhao, Y., Li, X., Jin, C., Chen, W., Meng, Z., 2020a. Study on the isolation of a terbutylazine degrading bacterium (Bacillus xiamenensis TBZ-Z5) and the construction of a microbial agent. Fresen. Environ. Bull. 29(8), 6446-6452.

59. Zhu, J., Fu, L., Li, X., Meng, Z. 2020b. Application of a prometryn-degrading bacterium, Arthrobacter crystallopoietes PCJ-S03 for bioremediation of prometryn pollution. Fresen. Environ. Bull. 29(7A), 6159-6167.

60. Zhu, J., Meng, Z., Fu, L., Jin, C., 2020c. Study on the biodegradation characteristics of atrazine and isolation of an atrazine degrading bacterium, Bacillus safensis ATR-Z5. Fresen. Environ. Bull. 29(8), 6412-6419.

\section{Figures}






Figure 1

Effect of PW/ES mixing ratio on the methane production in the co-digestion process. Error bars represent standard deviations of triplicate tests. 


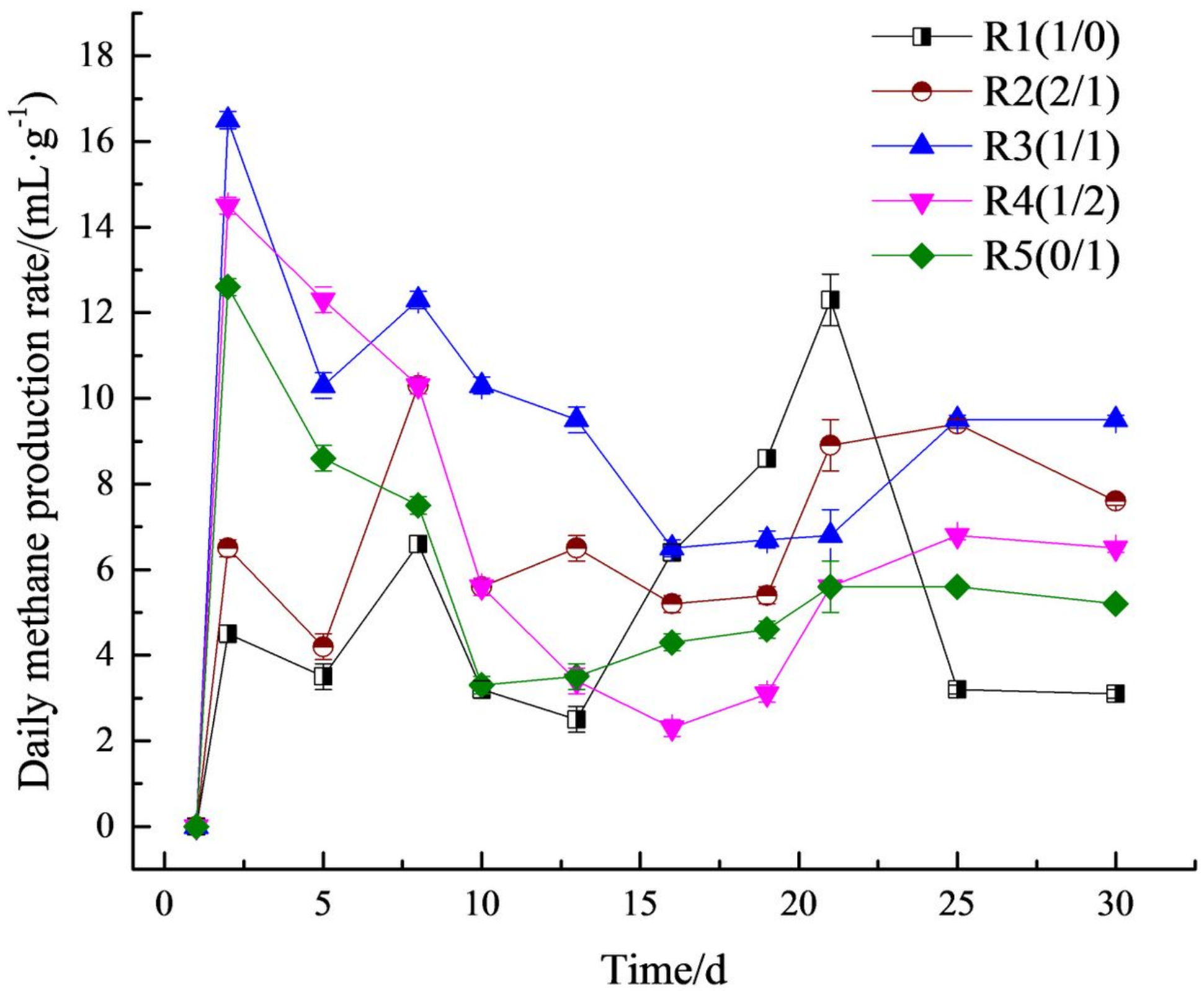

Figure 2

Effect of PW/ES mixing ratio on the daily methane production. Error bars represent standard deviations of triplicate tests. 


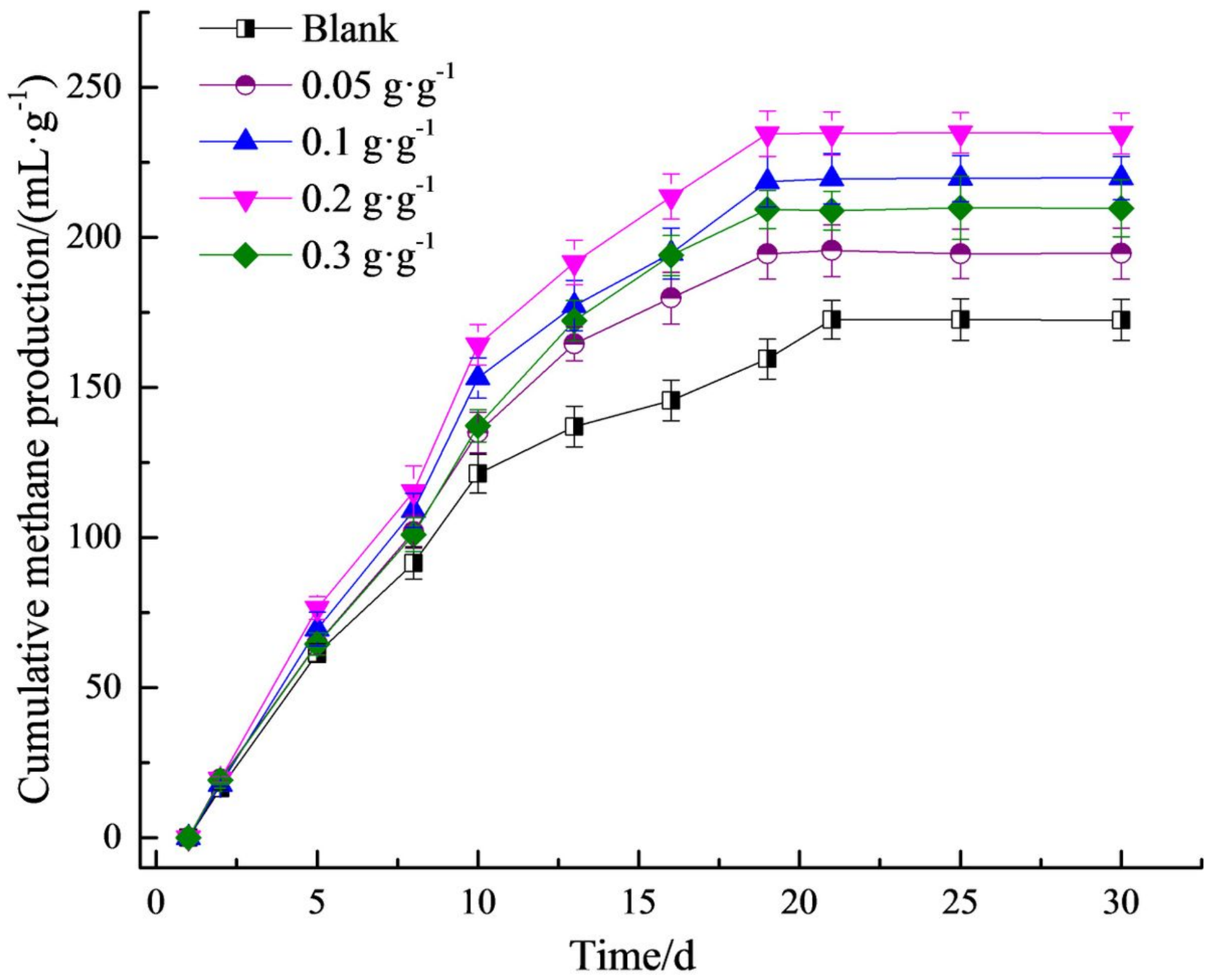

Figure 3

Effect of CP on the methane production from anaerobic co digestion of PW and ES. Error bars represent standard deviations of triplicate tests. 


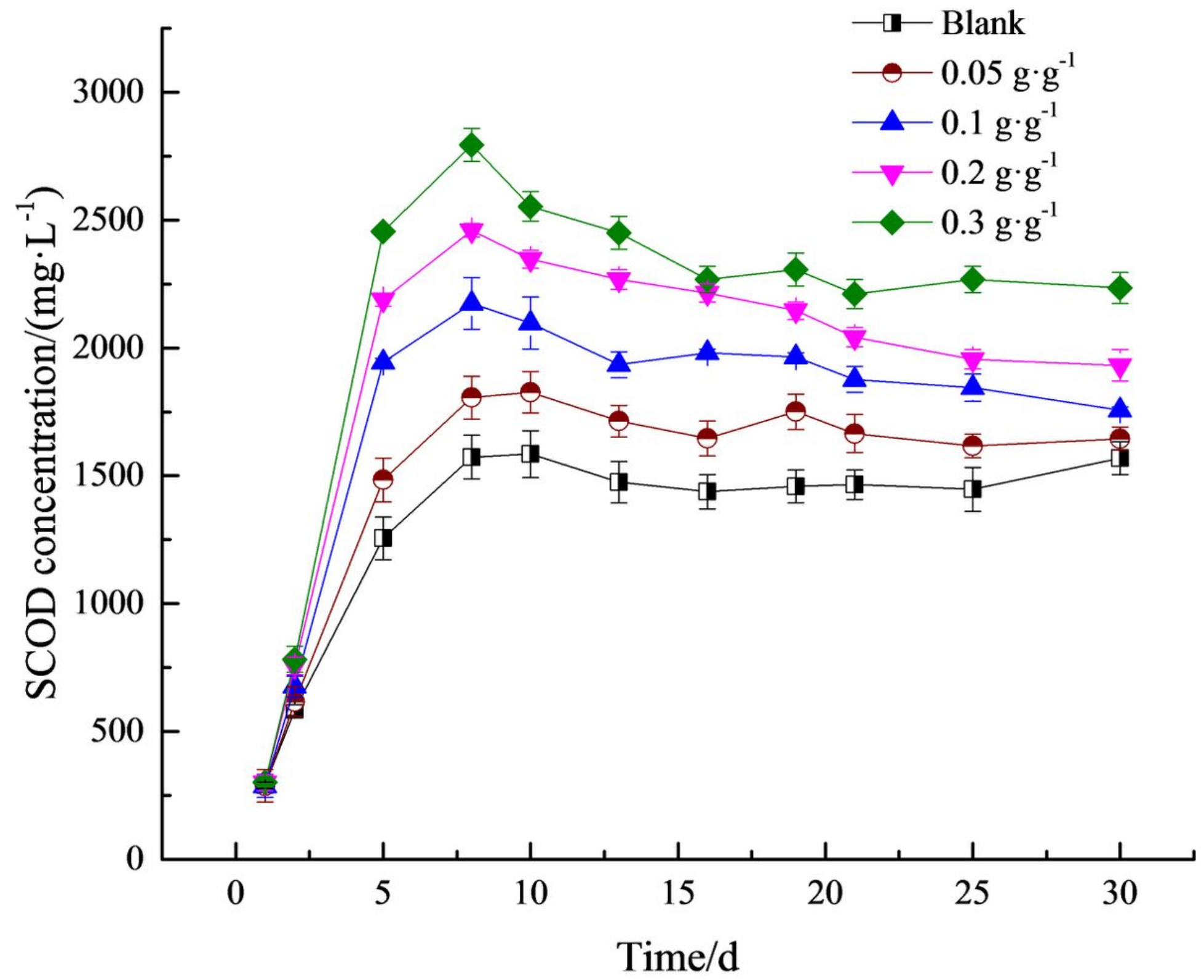

Figure 4

Effect of CP on the concentration of SCOD in PW and ES co-digestion system. Error bars represent standard deviations of triplicate tests. 

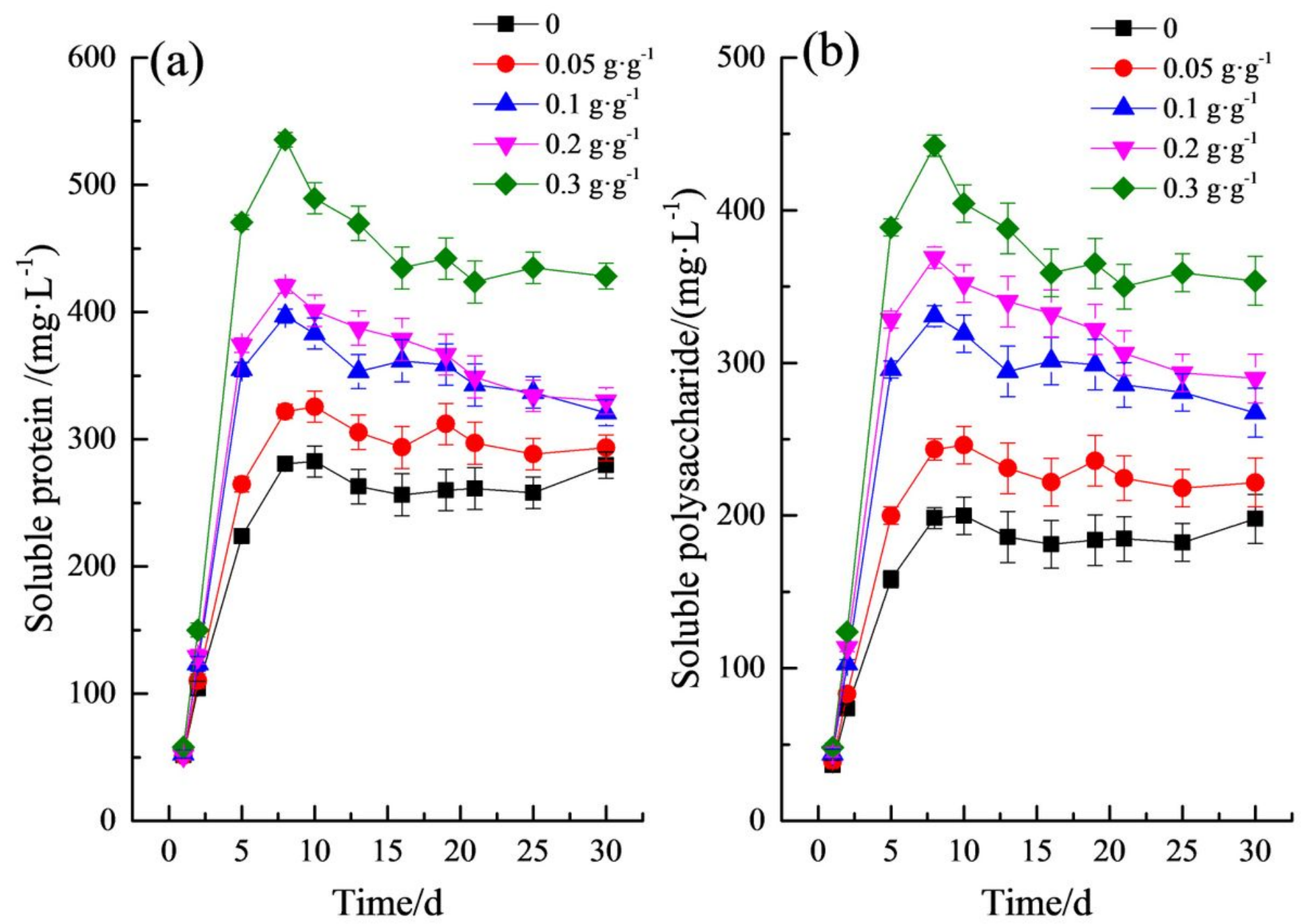

Figure 5

Effect of $\mathrm{CP}$ on the soluble protein and polysaccharide during anaerobic co-digestion of PW and ES. Error bars represent standard deviations of triplicate tests. 


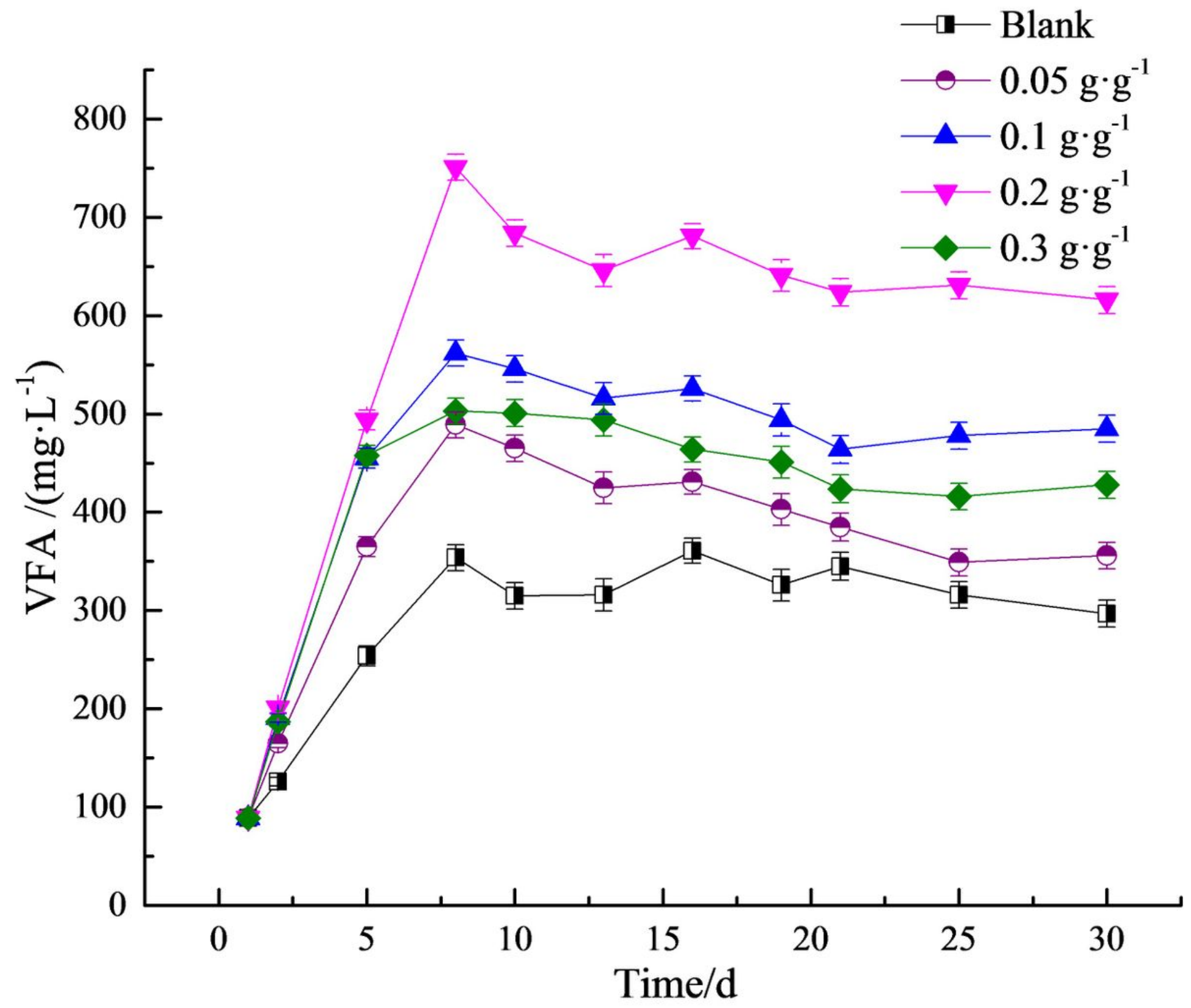

Figure 6

Effect of CP on VFA accumulation during anaerobic co-digestion of PW and ES. Error bars represent standard deviations of triplicate tests. 


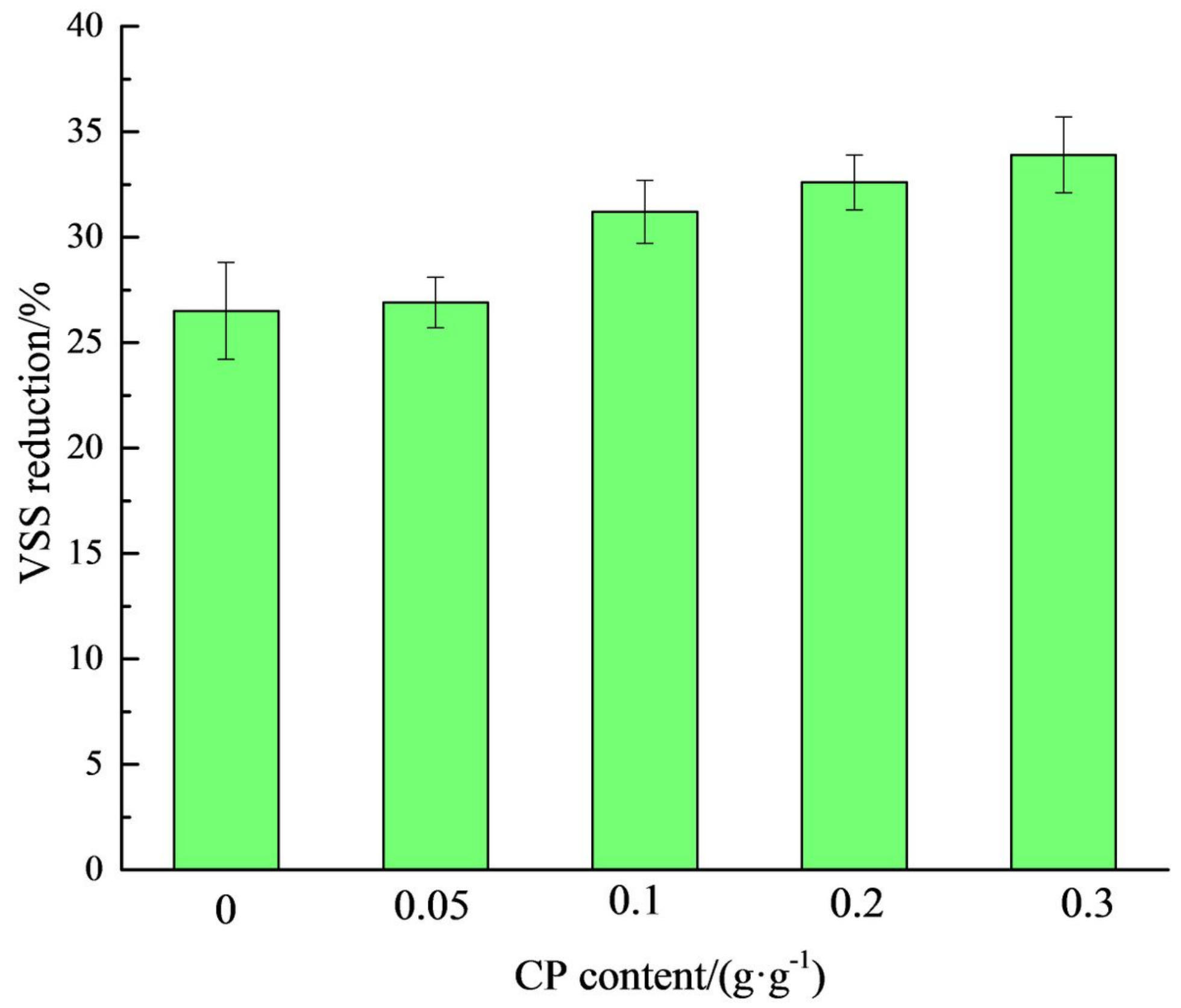

Figure 7

Effect of CP on the reduction of VSS in the co-digestion of PW and ES. Error bars represent standard deviations of triplicate tests 


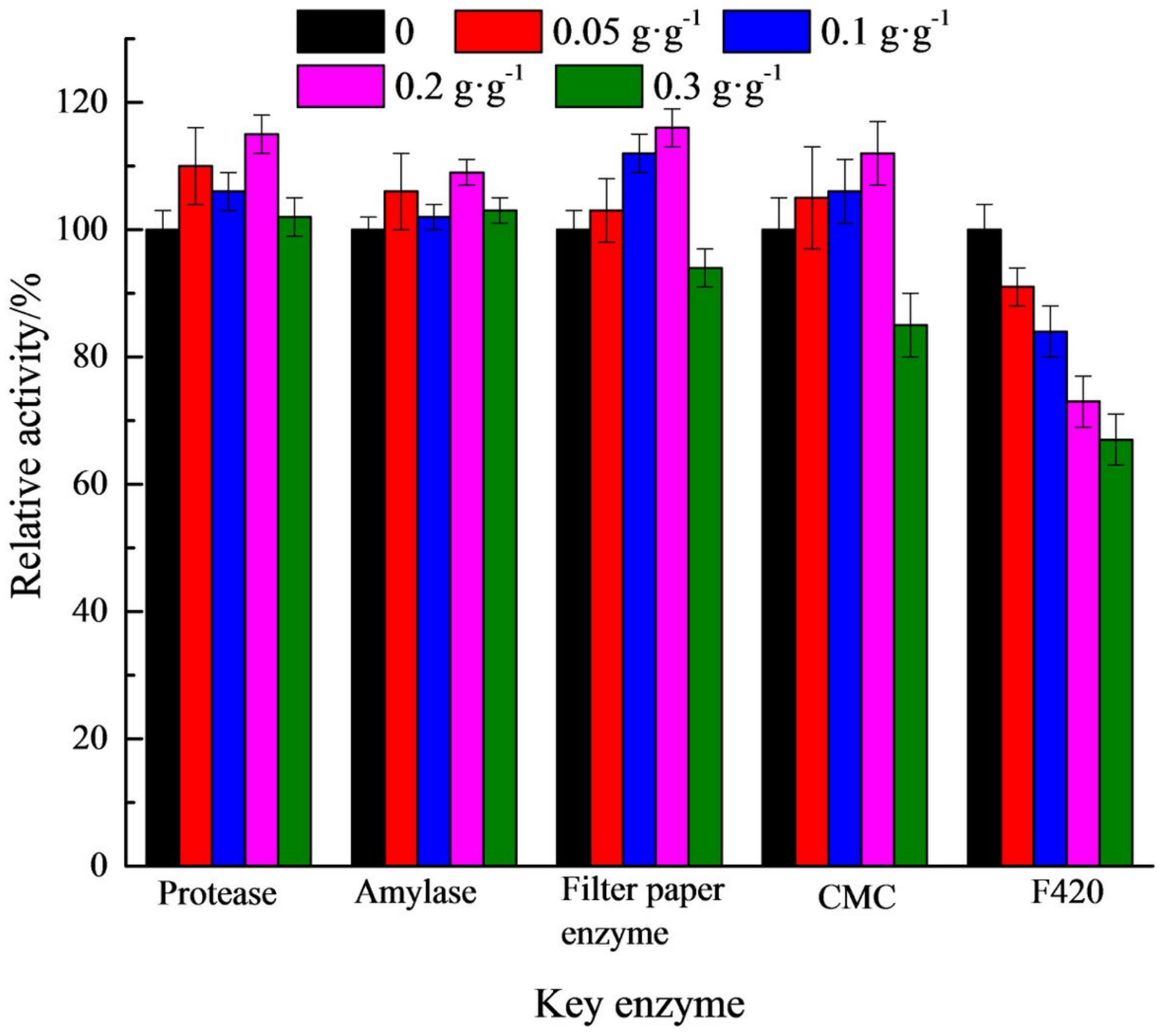

Figure 8

Effect of CP on the activities of key enzymes in anaerobic co-digestion of PW and ES. Error bars represent standard deviations of triplicate tests

\section{Supplementary Files}

This is a list of supplementary files associated with this preprint. Click to download.

- Supportinginformation.docx 